\title{
Austrian Syndrome: a report of an exceptionally rare and deadly syndrome
}

\author{
Síndrome de Austrian: descrição de uma entidade excepcionalmente \\ rara e mortal \\ Gustavo Nobre de Jesus ${ }^{1,2}\left(\mathbb{D}\right.$, Tânia Carvalho ${ }^{2}$, Alexandre Caldeira ${ }^{1}$, Susana M. Fernandes ${ }^{1,2}$ (D)
}

\begin{abstract}
Austrian Syndrome is the rare combination of a triad of endocarditis, meningitis, and pneumonia in the context of pneumococcal infection. Due to the involvement of several anatomical sites, the Austrian syndrome has a high mortality. Importantly, endocarditis is usually not considered during pneumococcal infection. We present a case of Austrian syndrome in a previously healthy 67-year-old woman. She featured with mental state alteration, respiratory failure, and shock, and was diagnosed with ceftriaxone-sensitive pneumococcal bacteremia, meningitis, and pneumonia. A transesophageal echocardiogram revealed vegetation of the mitral valve. Despite an improvement in her medical condition, she remained in a coma and died due to neurological complications. Even though the major cause of mortality in Austrian syndrome is cardiac involvement, meningitis is also linked with high morbidity and eventually death. We emphasize the relevance of an early diagnosis of the triad in order to decrease the very high mortality associated with this syndrome.
\end{abstract}

Keywords: Streptococcus pneumoniae; Meningitis; Pneumonia; Endocarditis.

\section{RESUMO}

A síndrome de Austrian é uma entidade extremamente rara, pautada por meningite, endocardite e pneumonia secundárias a doença pneumocócica invasiva. Devido à expressão multissistêmica, a mortalidade associada é elevada. Particularmente, a manifestação como endocardite é muitas vezes clinicamente insuspeita, carecendo de elevado índice de suspeita.Apresenta-se um caso de síndrome de Austrian numa doente do sexo feminino, 67 anos, previamente saudável. Clinicamente, apresentava coma, insuficiência respiratória e choque, tendo sido diagnosticada pneumonia e meningite, e com bacteremia a Streptococcus pneumoniae. Ecocardiograma transesofágico evidenciou uma vegetação na válvula mitral. Apesar da regressão do quadro respiratório, persistiu um quadro de coma, acabando a doente por morrer. Apesar da principal causa de morte descrita na síndrome de Austrian estar relacionada com complicações de endocardite, apresenta-se um caso único de apresentação e morte por meningite. Com poucos casos descritos mundialmente, sublinha-se a necessidade de um diagnóstico precoce desta tríade, motivo pelo qual relatamos o caso descrito.

Palavras-chave: Streptococcus pneumoniae; Meningite; Pneumonia; Encocardite.

\footnotetext{
${ }^{1}$ Serviço de Medicina Intensiva, Hospital de Santa Maria, Lisbon, Portugal.

2 Clínica Universitária de Medicina Intensiva, Faculdade de Medicina de Lisboa, Lisbon, Portugal.

$\bowtie$ Gustavo Nobre Jesus. Avenida Professor Egas Moniz, 1649-028 - Lisboa, Portugal. gustavo.jesus@chln.min-saude.pt | Recebido em: 01/02/2020 | Aprovado em: 09/07/2020
} 


\section{INTRODUCTION}

The triad of pneumonia, meningitis, and endocarditis caused by Streptococcus pneumoniae, also known as Austrian syndrome, is a very rare clinical entity. It is more frequent in patients with a history of alcoholism and has a high mortality rate $(32 \%)^{1}$, despite adequate antibiotic treatment. The outcome is mainly determined by cardiac valve destruction (most frequently, the aortic valve) and acute cardiac failure $^{2}$, although meningitis and respiratory failure also contribute to its high mortality.

We describe a case of Austrian syndrome in a previously healthy patient, with mitral endocarditis in the triad and death due to meningitis.

\section{CASE REPORT}

A previously healthy 67-year-old woman was admitted to the ICU for a sudden coma. She was found unresponsive at home for an indeterminate time. On admission, she had a Glasgow coma scale score (GCS) of 3, polypnea, and chest retraction. No meningeal signs were clinically evident. The patient was tachycardic (118 beats/minute), hypothermic $\left(33.3{ }^{\circ} \mathrm{C}\right)$, hypotensive (blood pressure of $91 / 56 \mathrm{~mm} \mathrm{Hg}$ ), and had peripheral cyanosis. The arterial blood gas count showed severe hypoxemia. Laboratory evaluation also revealed an acute kidney injury (serum creatinine $1.57 \mathrm{mg} / \mathrm{dL}$, urea $120 \mathrm{mg} / \mathrm{dL}$ ), hepatic injury (total bilirubin $3.45 \mathrm{mg} / \mathrm{dL}$, alanine aminotransferase $88 \mathrm{U} / \mathrm{L}$, aspartate aminotransferase $43 \mathrm{U} / \mathrm{L}$ ), rhabdomyolysis (creatine kinase $1373 \mathrm{U} / \mathrm{L}$ ), and elevated inflammatory markers (leukocytosis of $19.1 \times 10^{9} / \mathrm{L}, 95 \%$ neutrophils, and c-reactive protein of $48.78 \mathrm{mg} / \mathrm{dL}$ ).Lumbar puncture showed a xanthochromic cerebro-spinal fluid, with glucose $<20 \mathrm{mg} / \mathrm{dL}$, leukocytes $46 / \mathrm{mm}^{3}$ (predominance of polymorphonuclear leukocytes), and proteins $1110 \mathrm{mg} / \mathrm{dL}$. Blood, cerebrospinal fluid, and bronchial secretions cultures were positive for Streptococcus pneumoniae, sensitive to ceftriaxone. Chest radiography showed bilateral consolidation. A transesophageal echocardiogram was performed 24 hours after admission and revealed vegetation of the anterior mitral valve leaflet, with $7 \times 4 \mathrm{~mm}$. CT was performed and showed evidence of hydrocephalus, and an external ventricular drain was placed (Figure 1). On admission, the patient was intubated and started fluid resuscitation as well as vasopressors (norepinephrine, with a maximum dose of 0.22 $\mathrm{mcg} / \mathrm{Kg} / \mathrm{min}$ ). Initial empirical antibacterial therapy was made with ceftriaxone, clarithromycin, and vancomycin, de-escalated to ceftriaxone alone after acknowledgment of culture sensitivity tests. Dexamethasone was administered for five days. Clinical evolution on our unit was characterized by an improvement of inflammatory markers (CRP highest level was $39.1 \mathrm{mg} / \mathrm{dL}$, with a decrease to $7.43 \mathrm{mg} / \mathrm{dL}$ ), with the resolution of pneumonia, kidney, and hepatic injuries, as well as hydrocephalus, but the persistence of coma with a maximum GCS coma score of 4 , with extension to pain. Persistent lymphopenia during ICU stay was found, between 0.36 and $0.71 \%$. After excluding reversible causes like status epilepticus, a poor neurologic outcome was established, and she was treated with palliative care. She died on the $18^{\text {th }}$ day after admission.
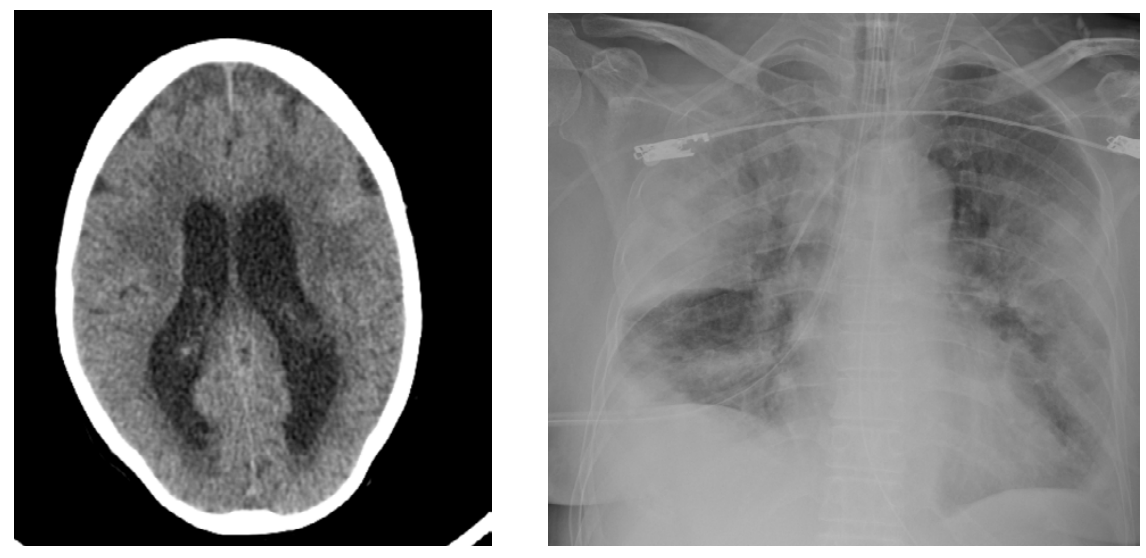

Figure 1. Sagital view of CT scan showing hydrocephalus $(A)$ and thoracic $x$-ray with bilateral infiltrates (B). 


\section{DISCUSSION}

First described by Robert Austrian in 1956, the Austrian syndrome is a systemic infection caused by Streptococcus pneumoniae. In small case series published, male gender, age, and alcoholism appear as risk factors ${ }^{3}$. This last one is associated with immunological defects such as impaired chemotaxis, dysfunctional reticuloendothelial system, and impaired delayed-type hypersensitivity ${ }^{4}$. Other predisposing factors capable of changing cellular immunocompetence like systemic corticotherapy, diabetes mellitus, splenectomy, and HIV infection ${ }^{3,5}$, have also been associated with this syndrome. Of note, in this series, $12 \%$ of the patients with Austrian Syndrome were previously healthy ${ }^{1}$. We might speculate that a non-described immune defect in apparently healthy individuals would explain the Austrian Syndrome. Our patient presented with persistent lymphopenia, but its etiology was unclear, and no other risk factor could be found.

Although this is the most frequent organism causing pneumonia and meningitis in adults, it is a rare cause $(3 \%)$ of endocarditis ${ }^{6}$ and is frequently not considered an agent of endocarditis until symptoms develop. Pneumonia seems to be the first element of the triad ${ }^{1}$. Then, by systemic dissemination, S. pneumoniae spreads to the central nervous system ${ }^{7}$ and/or the heart ${ }^{8}$. If endocarditis is a consequence of meningitis or vice versa is unknown ${ }^{9}$. A particularity in our case is the simultaneous diagnosis of pneumonia, meningitis, and endocarditis at presentation. It has been described that in the presence of bacterial meningitis, $17 \%$ of patients develop pneumonia as a complication, but only $2.3 \%$ develop endocarditis ${ }^{10}$. Others have claimed a higher prevalence of Austrian syndrome in the presence of endocarditis ${ }^{11}$. Although bacterial meningitis has a low incidence (1-2 cases per 100,000 adults, annually $\left.{ }^{12}\right)$, mainly thanks to the widespread of vaccination, $18-30 \%$ of patients die, and in half of the survivors, neurological sequelae occur, most commonly hearing loss and cognitive deficits ${ }^{13}$. In our case, it was meningitis that presented the most severe features and eventually leads to patient death. In previous cases, endocarditis with complications (valvular regurgitation, perforation, congestive heart failure, perivalvular abscesses, and systemic embolization due to the formation of large vegetations), underlies the high mortality rate in Austrian syndrome ${ }^{3,12}$. Our case involved the mitral valve, and the need for surgical intervention was excluded.

The Austrian syndrome has an acute and highly aggressive clinical evolution. Our case report aims to emphasize this complex association, highlighting that in a patient with pneumococcal pneumonia and/or meningitis, and particularly bacteremia must raise awareness on the possibility of concomitant endocarditis. Early diagnosis and suitable treatment can only be achieved through high clinical suspicion.

\section{Acknowledgements}

This study received no financial support.

\section{Conflicts of interest}

The authors declare that there is no conflict of interest regarding the publication of this article.

\section{Informed consent}

The patient's identity has been fully preserved.

\section{REFERENCES}

1. Nogué MR, Arraiz I, Martín G et al, Revisión Síndrome de Austrian : Una rara manifestación de la enfermedad neumocócica invasiva. Presentación de un caso y revisión bibliográfica. Rev. Española Quimioter. 2019; 32: 2.

2. Austrian R. The syndrome of pneumococcal endocarditis, meningitis and rupture of the aortic valve. Trans Am Clin Climatol Assoc. 1956-1957;68:40-7

3. Kanakadandi V, Annapureddy, N, Agarwal SK et al. The Austrian syndrome: a case report and review of the literature. Infection. 2013;41,695-700

4. Velazquez C, Araji O, Barquero J et al. Austrian syndrome: A clinical rarity. Int. J. Cardiol. 2008; 127: 2.

5. Nog R, Zaheer N, Badshah C. Austrian syndrome (Triad of pneumococcal pneumonia, meningitis and endocarditis) in an intravenous drug user: A case report. Infect. Dis. Clin. Pract. 2010;18: 6. 
6. Straus AL, Hamburger M. Pneumococcal endocarditis in the penicillin era. Arch Intern Med. 1966 Sep;118(3):190-8

7. Henriques-Normark B, Tuomanen EI. The pneumococcus: epidemiology, microbiology, and pathogenesis. Cold Spring Harb Perspect Med. 2013 Jul 1;3(7):a010215.

8. Kan B, Ries J, Normark B et al. Endocarditis and pericarditis complicating pneumococcal bacteraemia, with special reference to the adhesive abilities of pneumococci: Results from a prospective study. Clin. Microbiol. Infect. 2006; 12: 4.

9. Lucas MJ, Brouwer MC, van der Ende A, van de Beek D. Endocarditis in adults with bacterial meningitis. Circulation. 2013 May 21;127(20):2056-62.

10. Daniels CC, Rogers PD, Shelton CM. A Review of Pneumococcal Vaccines: Current Polysaccharide
Vaccine Recommendations and Future Protein Antigens. J Pediatr Pharmacol Ther. 2016;21(1):27-35. doi:10.5863/1551-6776-21.1.27.

11. de Egea $V$, Muñoz $P$, Valerio $M$, et al. Characteristics and Outcome of Streptococcus pneumoniae Endocarditis in the XXI Century: A Systematic Review of 111 Cases (2000-2013). Medicine. 2015 Sep;94(39):e1562

12. McGill F, Heyderman RS, Panagiotou $S$, Tunkel AR, Solomon T. Acute bacterial meningitis in adults. Lancet. 2016 Dec 17;388(10063):3036-3047.

13. Engelen-Lee JY, Brouwer MC, Aronica E, van de Beek D. Pneumococcal meningitis: clinical-pathological correlations (MeninGene-Path). Acta Neuropathol Commun. 2016;4:26. Published 2016 Mar 22. doi:10.1186/s40478-016-0297-4 